\title{
Susceptibility of Winter Wheat and Triticale to Yellow Rust Influenced by Complex Interactions between Vernalisation, Temperature, Plant Growth Stage and Pathogen Race
}

\author{
Julian Rodriguez-Algaba ${ }^{1, *}$, Chris K. Sørensen ${ }^{1}$, Rodrigo Labouriau ${ }^{2}$, Annemarie F. Justesen ${ }^{1}$ \\ and Mogens S. Hovmøller ${ }^{1}$ \\ 1 Department of Agroecology, Faculty of Science and Technology, Aarhus University, Forsøgsvej 1, \\ 4200 Slagelse, Denmark; chris.sorensen@agro.au.dk (C.K.S.); annemariefejer.justesen@agro.au.dk (A.F.J.); \\ mogens.hovmoller@agro.au.dk (M.S.H.) \\ 2 Department of Mathematics, Faculty of Science and Technology, Aarhus University, Ny Munkegade 118, \\ 8000 Aarhus, Denmark; rodrigo.labouriau@math.au.dk \\ * Correspondence: julianr.algaba@agro.au.dk
}

Received: 13 November 2019; Accepted: 17 December 2019; Published: 20 December 2019

\begin{abstract}
Environmental factors influence the disease susceptibility of crop plants. In this study, we established an experimental system to investigate the effects of vernalisation, temperature and plant growth stage on the susceptibility of winter wheat and winter triticale to Puccinia striiformis, the causal agent of yellow (stripe) rust. Two temperature regimes: standard $\left(18{ }^{\circ} \mathrm{C}\right.$ day/ $12{ }^{\circ} \mathrm{C}$ night) and low $\left(12{ }^{\circ} \mathrm{C}\right.$ day $/ 6^{\circ} \mathrm{C}$ night), vernalised and non-vernalised seedlings, vernalised adult plants and two pathogen races were investigated. At low temperatures, vernalisation reduced the susceptibility of seedlings exposed to the 'Warrior' race, while this was only the case for five out of eight varieties exposed to the 'Kranich' race. Changing from standard to low temperature resulted in increased susceptibility of non-vernalised seedlings of seven varieties inoculated with the 'Warrior' race and five varieties inoculated with the 'Kranich' race. Increased susceptibility at low temperature was also detected for several varieties at the adult plant growth stage. Comparisons between vernalised seedlings and adult plants revealed an effect of plant growth stage on disease susceptibility (e.g., Adult Plant Resistance) in five varieties at standard temperature for the 'Warrior' race and in five and four varieties at standard and low temperature respectively, for the 'Kranich' race. The complex and unpredictable interactions between environment and pathogen influencing yellow rust susceptibility of individual varieties stress the importance of phenotyping for disease resistance under different environmental conditions and pathogen populations. The environmental impact on rust susceptibility should also be taken into account in early-warning systems targeting wheat and triticale breeding programmes and growers.
\end{abstract}

Keywords: host susceptibility; environmental factors; Puccinia strifformis; stripe rust; Triticum spp.; $\mathrm{x}$ Triticosecale

\section{Introduction}

Winter crops of wheat (Triticum spp.) and triticale (x Triticosecale) acquire the capacity to flower and develop seeds after prolonged exposure to low temperatures, i.e., vernalisation [1,2]. During the process of vernalisation, overwintering crops also acquire increased tolerance to cold temperatures and capacity to combat plant pathogens by secretion of both antifreeze $[3,4]$ and pathogenesis-related (PR) proteins [5-7], respectively. The effect of vernalisation and the corresponding ability to influence 
disease susceptibility in winter cereals has been extensively investigated for the pink snow mold (Microdochium nivale) [8,9] and to a lesser extent, to powdery mildew (Blumeria graminis f.sp. hordei) [10]. However, no studies have so far been reported on the effect of vernalisation on the susceptibility to rust fungi in winter cereals.

In addition to vernalisation, temperature may strongly affect host-pathogen interactions. The influence of temperature on changes in susceptibility to rust fungi has been widely studied in several cereal-rust pathosystems, e.g., P. striiformis $[11,12]$, P. graminis $[13,14]$ and P. triticina $[15,16]$. Puccinia striiformis, the fungus causing yellow (stripe) rust, has been reported to be sensitive to environmental conditions, e.g., temperature, light intensity and dew formation, which significantly influence infection efficiency and growth in the cereal host [17]. Furthermore, the effectiveness of genes for resistance to wheat rusts may depend on temperature and plant growth stage, leading to different disease responses [14,18-20]. Thus, environmental factors are important determinants of the host-pathogen interaction phenotype. Up to now, reports on how the interaction between vernalisation and temperature affect the susceptibility of winter wheat and winter triticale to the yellow rust fungus are lacking.

The deployment of disease-resistant host varieties has proven to be an efficient, economically and environmentally sound approach to control P. striiformis. Generally, the interaction between Puccinia spp. and the cereal host often follows the classical gene-for-gene model. Basically, this involves specific resistance (R-gene) and avirulence (Avr) genes in the host and the pathogen, respectively [21]. The resistant phenotype (reflecting an incompatible interaction) results from the interaction between Avr-gene and R-gene products that trigger resistance in the plant. When the Avr-gene product is not recognized by the host plant, then a susceptible phenotype (or compatible interaction) may develop [22]. Two major types of rust resistance are often used in wheat and triticale breeding programmes to control P. striiformis, i.e., all-stage/seedling resistance and adult plant resistance (APR). All-stage resistance is expressed through all growth stages of the cereal host, it is often specific to certain races of the pathogen and conferred by individual R-genes with major effects, which can easily be overcome by new races [23-25]. Conversely, APR is expressed at adult plant stages, it may be race-specific or non-race-specific and is considered more durable than seedling resistance. Individual APR genes may confer partial resistance, but when based on multiple genes with additive effects near complete resistance can be achieved [26-28]. The expression of some APR genes may depend on temperature, e.g., high-temperature adult-plant (HTAP) resistance, which is only effective at warm temperatures [11,29].

The aim of the present study was to investigate the influence of host vernalisation, temperature and plant growth stage on the susceptibility of winter wheat and winter triticale to specific $P$. striiformis races. Potential shifts in disease susceptibility were investigated in seedlings exposed to $+/-$ cold pre-treatment (vernalisation), followed by two different temperature regimes, and in adult plants under the same temperature regimes. Understanding how environmental factors may affect disease susceptibility would help in the design of future protocols for phenotyping of disease resistance and in the development of robust and reliable early-warning systems for yellow rust, targeting wheat and triticale breeding programmes and agricultural advisory services.

\section{Materials and Methods}

\subsection{Pathogen Isolates and Host Varieties}

Two Puccinia striiformis isolates representing the 'Warrior' and 'Kranich' races were used in the present study [30]. Isolate identity and purity were confirmed by molecular genotyping using 19 microsatellite markers and race phenotyping using a set of wheat differential genotypes carrying 21 previously characterised resistance genes [30-32]. The virulence phenotypes of the two P. striiformis isolates are shown in Table 1. Isolate DK28/12 of the 'Kranich' race, collected in 2012 from triticale variety (var.) Tulus, and isolate DK09/11 of the 'Warrior' race, collected in 2011 from wheat var. Holeby, were selected to test the effect of vernalisation, temperature and plant growth stage on shifts in 
susceptibility to yellow rust in a number of agronomically important wheat and triticale var., i.e., Jensen, Hereford, and Substance (wheat), and Gringo, Tulus, Dinaro and Travoris (triticales) (www.sortinfo.dk), in addition to VPM1, a wheat differential line carrying Yr17 [33]. Anja and Croplan Genetics 514W (wheat) were selected as susceptible controls $[34,35]$. Wheat and triticale varieties were obtained from Tystofte Foundation, Denmark, except VPM1 (Claude de Vallavieille-Pope, INRA, France) and Croplan Genetics 514W (Eugene A. Milus, Univ. Arkansas, AR, USA).

Table 1. Virulence phenotype of Puccinia striiformis isolates DK09/11 ('Warrior' race) and DK28/12 ('Kranich' race). Figures and symbols designate virulence and avirulence (-) corresponding to yellow rust resistance genes and the resistance specificity of Strubes Dickkopf (Sd); Suwon-Omar (Su); Spaldings Prolific (Sp); Avocet S (AvS); and Ambition (Amb).

\begin{tabular}{lcccccccccccccccccccccc}
\hline & \multicolumn{11}{c}{ Virulence Phenotype } \\
\cline { 2 - 6 } Isolates & 1 & 2 & 3 & 4 & 5 & 6 & 7 & 8 & 9 & 10 & 15 & 17 & 24 & 25 & 27 & 32 & Sd & Su & Sp & AvS & $A m b$ \\
\hline DK09/11 & 1 & 2 & 3 & 4 & - & 6 & 7 & - & 9 & - & - & 17 & - & 25 & - & 32 & Sd & Su & Sp & AvS & Amb \\
DK28/12 & 1 & 2 & 3 & - & - & 6 & 7 & 8 & 9 & - & - & 17 & - & 25 & - & 32 & Sd & - & - & AvS & Amb \\
\hline
\end{tabular}

\subsection{Experimental Procedure}

\subsubsection{Vernalised and Non-Vernalised Seedling Test}

The shifts in susceptibility to $P$. striiformis were investigated in seedlings exposed to two treatments, i.e., no cold pre-treatment (non-vernalised) or cold pre-treatment to induce vernalisation, followed by two different temperature regimes. Before vernalisation, seeds of each variety were placed on individual transparent plastic trays containing wet felt and blotting paper. These were covered with lids and kept in a climate chamber for seed germination at $17^{\circ} \mathrm{C}$ for $5-6$ days with a photoperiod of $22-27 \mu \mathrm{mol} \mathrm{s}^{-1} \mathrm{~m}^{-2}$ for $12 \mathrm{~h}$. Vernalisation was induced by transferring the germinated seedlings into a climate chamber for 8 weeks at $5{ }^{\circ} \mathrm{C}$ with a photoperiod of $15-18 \mu \mathrm{mol} \mathrm{s}^{-1} \mathrm{~m}^{-2}$ for $16 \mathrm{~h}$. After vernalisation, three seedlings of each variety were transferred to $17 \mathrm{~cm}$ square pots containing an organic substrate with slow-release plant nutrients (UNIMULD, Pindstup Mosebrug A/S, Ryomgaard, Denmark). For the non-vernalised plants, three seeds of each variety were directly sown under the same conditions described above 12 days before the vernalised plants were prepared to be transferred into pots. Thus, both vernalised and non-vernalised seedlings reached a similar two-leaf growth stage. All seedlings were subsequently grown in spore-proof greenhouse cabins at two different temperature regimes $\left(18{ }^{\circ} \mathrm{C}\right.$ day $/ 1{ }^{\circ} \mathrm{C}$ night (standard temperature) and $12{ }^{\circ} \mathrm{C}$ day $/ 6{ }^{\circ} \mathrm{C}$ night (low temperature)) with alternating periods of $16 \mathrm{~h}$ light and $8 \mathrm{~h}$ darkness, and supplementary artificial light of $200 \mu \mathrm{mol} \mathrm{s}^{-1} \mathrm{~m}^{-2}, 70-80 \%$ relative humidity (RH), except for $24 \mathrm{~h}$ incubation in a dew chamber following inoculation at $10{ }^{\circ} \mathrm{C}, 100 \% \mathrm{RH}$. Three replicates, each consisting of three sub-replicates, i.e., 3 seedlings per pot $\times 3$ pots, per variety of non-vernalised and vernalised plants, were included for each temperature regime. All treatments were represented within an individual experimental unit (spore-proof greenhouse cabin) following a completely randomised block design. In some cases, fewer sub-replicates were scored for disease susceptibility due to unsuccessful inoculation. For inoculation, $2 \mathrm{mg}$ of urediniospores of each pathogen isolate were suspended in $1 \mathrm{~mL}$ of an engineered fluid (NOVEC ${ }^{\mathrm{TM}} 7100,3 \mathrm{M}$, USA) and $2 \mu \mathrm{L}$ of the spore suspension was point inoculated on the middle part of the second leaf with an electronic 1-channel pipette (eLine ${ }^{\circledR} 0.2-10 \mu \mathrm{L}$, Sartorius, Finland) according to Sørensen et al. [36]. Subsequently, plants were mist-sprayed with distilled water and incubated in a dew chamber at $10{ }^{\circ} \mathrm{C}$ in darkness, $100 \% \mathrm{RH}$, for $24 \mathrm{~h}$. Plants were transferred to spore-proof greenhouse cabins and kept under the same conditions described above. The latent period, i.e., time from inoculation to initial appearance of urediniospores [37], was assessed in susceptible varieties, e.g., Anja and Croplan Genetics 514W, at both temperature regimes (data not shown). Disease assessment was performed by visual assessment of the infection type (IT) on a 0-9 scale [38], 15 days after inoculation (dai) at standard and 20 dai at low temperature, based on differences in the latent period assessed on susceptible varieties. 
Subsequently, plants were scored a second time 23 and 25 dai respectively, to assure that the disease responses observed at low temperature were not confounded by slow disease development. Virulence phenotyping was based on the phenotypic interpretation of IT responses observed on individual leaves of wheat and triticale varieties.

\subsubsection{Vernalised Adult Plant Test}

After disease assessment of vernalised seedlings, infected leaves were removed, and RH was lowered to approximately $50 \%$ for $48 \mathrm{~h}$ to prevent secondary P. striiformis infections on experimental plants. One seedling per variety and pot was kept and grown under the same temperature regimes as previously described and trimmed during stem elongation and booting to maintain three tillers per plant. Tillers were individually inoculated at growth stage 50, i.e., when the first spikelet of the inflorescence was just visible [39], approximately 8 weeks after detachment of the infected seedling leaves. Inoculation was performed using an airbrush spray gun (standard class, Revell GmbH, Germany) on an area of $2 \times 2 \mathrm{~cm}$ on the flag (F) and F-1 leaves with a spore suspension of $2 \mathrm{mg}$ of urediniospores per $\mathrm{ml}$ of engineered fluid (NOVEC ${ }^{\mathrm{TM}} 7100,3 \mathrm{M}$, St. Paul, MN, USA). The inoculated area was restricted by using a plastic template positioned on the leaf surface. Three replicates each consisting of six sub-replicates, i.e., $(3 \times \mathrm{F}$ and $3 \times \mathrm{F}-1$ leaves per pot $) \times 3$ pots, per variety and temperature regime were included on each individual experimental unit following a completely randomized block design. Unsuccessful inoculation reduced the number of sub-replicates in some cases. The latent period was assessed on susceptible varieties (data not shown) before IT assessment (0-9 scale), 24 dai at standard temperature and 28 dai at low temperature.

\subsection{Data Analysis}

The probabilities of successful inoculation, i.e., observed disease responses, reported in Tables 2 and 3, were estimated for each combination of variety, treatment and pathogen race, using the binomial logistic model described below. For Table 2, each treatment consisted of a combination of leaf type (flag and F-1) and temperature regimen (standard or low) and for Table 3, a combination of cold pre-treatment (vernalised or non-vernalised) and temperature regimen (standard or low). The binomial logistic model utilised included an interaction between variety and treatment, the random variable $Y_{c t r}$ representing the result of the inoculation of $r$ th replicate of $v$ th variety subjected to $t$ th treatment (successful $=1$, otherwise $=0$ ) and binomially distributed with size 1 and probability of success $\rho_{v t r}$, where:

$$
\log i t\left(\rho_{v t r}\right)=\theta_{v t}
$$

Thus, the probability for each combination of variety and treatment was estimated by applying the inverse logistic transformation to the corresponding parameter $\theta_{v t}$. A likelihood ratio test was used to make a global test of possible differences between the parameters representing the treatments for each variety $[40,41]$. The infection types resulting from different combinations of treatments for seedlings and adult plants were quantified using the medians of the infection types across replicates for each combination of pathogen race and variety. Since disease assessments were based on an ordinal scale, the comparisons between different treatments were performed using Monte Carlo permutation tests with 10,000 bootstrap permutations [42]. When significant differences were detected, both for the binomial model of the proportion of successful inoculations and infection types, pairwise post hoc analyses were performed to identify which pairs of treatments were significantly different. The $p$-values were adjusted for multiple comparisons using the controlled false discovery rate (FDR) method [43,44]. The binomial generalised linear mixed models were adjusted using the R-package "lme4". All statistical analyses were performed using R software version 3.6.1 [45]. 


\section{Results}

\subsection{Experimental System}

High inoculation success rates were achieved for all treatments, varying from $61-98 \%$ for seedlings and from 52-76\% for adult plants (Supplementary Tables S1 and S2). In general, inoculation success was not affected by pathogen race (Supplementary Table S3) or leaf number of adult plants, except for Jensen (Table 2). Inoculation success was higher for vernalised seedlings compared to non-vernalised seedlings, the differences being significant for Anja and Hereford (wheat), and Dinaro (triticale) (Table 3). Particular combinations of varieties, vernalisation, leaf number on adult plants and temperature regimes resulted in higher or lower inoculation success, but no systematic differences among varieties were observed (Tables 2 and 3). Unintentional secondary infections were not observed on experimental adult plants after manual removal of infected seedling leaves followed by low relative humidity. Distinct infection types (IT) were scored individually on all successfully inoculated leaves (Figures 1 and 2), except for vernalised seedling control plants of Anja inoculated with the 'Warrior' race and grown at low temperature. In this case, it was not possible to assign an IT according to the 0-9 scale, i.e., few sporadic pustules with weak or no sporulation (Figure 1E). The compatible interactions for vernalised seedlings of 514W and Gringo ('Warrior' race), grown at low temperature, appeared as restricted sporulating areas with no or minor presence of chlorotic and/or necrotic symptoms (Figure 1E). The variability in IT scores for individual leaves of individual treatments is presented as box plots (Supplementary Figure S1).

Table 2. Probability of inoculation success of flag (F) and F-1 leaves of adult plants of winter wheat and winter triticale varieties after inoculation with the 'Warrior' and the 'Kranich' race of Puccinia striiformis and maintained at two temperature (Temp.) regimes, i.e., $18{ }^{\circ} \mathrm{C}$ day/ $12{ }^{\circ} \mathrm{C}$ night (standard temperature) and $12{ }^{\circ} \mathrm{C}$ day $/ 6{ }^{\circ} \mathrm{C}$ night (low temperature). Different letters (in bold) within a row indicate significant differences among treatments $(p \leq 0.05)$.

\begin{tabular}{cccccc}
\hline Variety & $\boldsymbol{p}$-Value & $\begin{array}{c}\text { Flag Leaf Standard } \\
\text { Temp. }\end{array}$ & $\begin{array}{c}\text { F-1 LeafStandard } \\
\text { Temp. }\end{array}$ & $\begin{array}{c}\text { Flag Leaf Low } \\
\text { Temp. }\end{array}$ & $\begin{array}{c}\text { F-1 Leaf Low } \\
\text { Temp. }\end{array}$ \\
\hline Anja & 0.106 & 0.39 & 0.78 & 0.78 & 0.72 \\
514W & 0.062 & 0.83 & 0.83 & 0.72 & 0.39 \\
Jensen & 0.004 & $\mathbf{0 . 3 3 c}$ & $\mathbf{0 . 6 7 b}$ & $\mathbf{0 . 9 4 a}$ & $\mathbf{0 . 8 2 b}$ \\
Hereford & 0.098 & 0.72 & 0.67 & 0.61 & 0.69 \\
Substance & 0.699 & 0.50 & 0.61 & 0.78 & 0.56 \\
VPM1 & 0.098 & 0.61 & 0.61 & 0.56 & 0.53 \\
Gringo & 0.982 & 0.56 & 0.56 & 0.61 & 0.61 \\
Tulus & 0.098 & 0.61 & 0.61 & 0.61 & 0.56 \\
Dinaro & 0.982 & 0.72 & 0.61 & 0.78 & 0.72 \\
Travoris & 0.063 & 0.67 & 0.67 & 0.56 & 0.22 \\
\hline
\end{tabular}

Table 3. Probability of inoculation success on non-vernalised and vernalised seedlings of winter wheat and winter triticale varieties after inoculation with the 'Warrior' and the 'Kranich' race of Puccinia striiformis and maintained at two temperature (Temp.) regimes, i.e., $18{ }^{\circ} \mathrm{C}$ day $/ 12{ }^{\circ} \mathrm{C}$ night (standard temperature) and $12{ }^{\circ} \mathrm{C}$ day $/ 6{ }^{\circ} \mathrm{C}$ night (low temperature). Different letters (in bold) within a row indicate significant differences among treatments $(p \leq 0.05)$.

\begin{tabular}{cccccc}
\hline Variety & $\boldsymbol{p}$-Value & $\begin{array}{c}\text { Non-Vernalised Seedlings } \\
\text { Standard Temp. }\end{array}$ & $\begin{array}{c}\text { Vernalised Seedlings } \\
\text { Standard Temp. }\end{array}$ & $\begin{array}{c}\text { Non-Vernalised } \\
\text { Seedlings Low Temp. }\end{array}$ & $\begin{array}{c}\text { Vernalised Seedlings } \\
\text { Low Temp. }\end{array}$ \\
\hline Anja & 0.016 & $\mathbf{0 . 7 8 b}$ & $\mathbf{0 . 9 4 a}$ & $\mathbf{0 . 6 1 b}$ & $\mathbf{1 . 0 0 a}$ \\
$514 \mathrm{~W}$ & 0.070 & 0.83 & 1.00 & 0.72 & 0.94 \\
Jensen & 0.420 & 0.67 & 0.78 & 0.61 & $\mathbf{0 . 7 2 b}$ \\
Hereford & 0.016 & $\mathbf{0 . 6 7 b}$ & $\mathbf{1 . 0 0 a}$ & 0.72 & 0.94 \\
Substance & 0.070 & 0.89 & 0.83 & 0.50 & 0.94 \\
VPM1 & 0.083 & 0.61 & 0.89 & 0.83 & 0.94 \\
Gringo & 0.069 & 0.72 & 1.00 & 0.89 & 0.94 \\
Tulus & 0.420 & 0.94 & $\mathbf{0 . 8 3 a}$ & $\mathbf{0 . 5 0 b}$ & 0.89 \\
Dinaro & 0.016 & $\mathbf{0 . 4 4 b}$ & 1.00 & 0.89 & 0.94 \\
Travoris & 0.070 & 0.72 & & \\
\hline
\end{tabular}



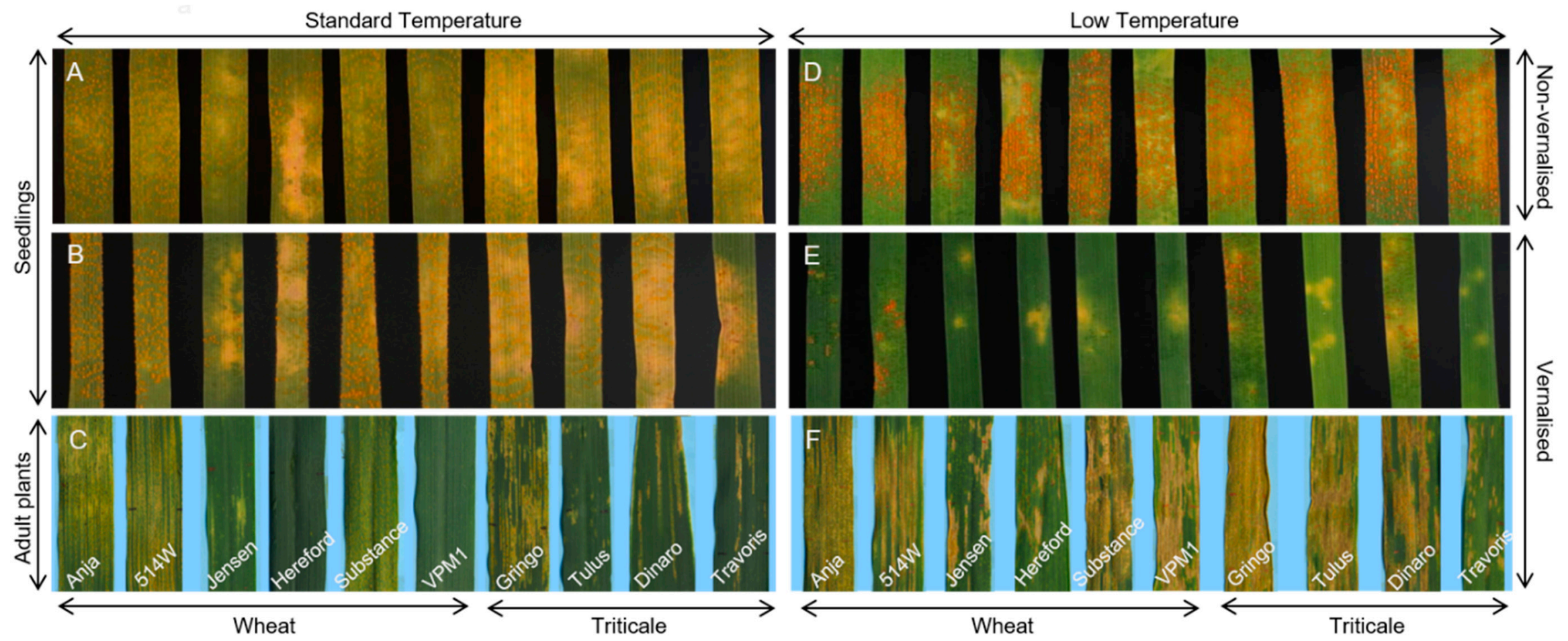

Wheat

Triticale

Figure 1. Isolate DK09/11 ('Warrior' race): Effect of vernalisation and temperature on yellow rust susceptibility on winter wheat and winter triticale seedlings (second leaf) and adult plants (flag leaf). The leaves are representative of infection types observed across replicates. Plants in (A-C) were kept at $18^{\circ} \mathrm{C}$ day $/ 12{ }^{\circ} \mathrm{C}$ night (standard temperature). Seedlings were scored 15 days after inoculation (dai) and adult plants 24 dai. Plants in (D-F) were kept at $12{ }^{\circ} \mathrm{C}$ day $/ 6{ }^{\circ} \mathrm{C}$ night (low temperature). Seedlings were scored 20 dai and adult plants 28 dai. (A,D): Non-vernalised seedlings. (B,E): Vernalised seedlings. (C,F): Vernalised adult plants. Anja and 514W were included as susceptible controls. 


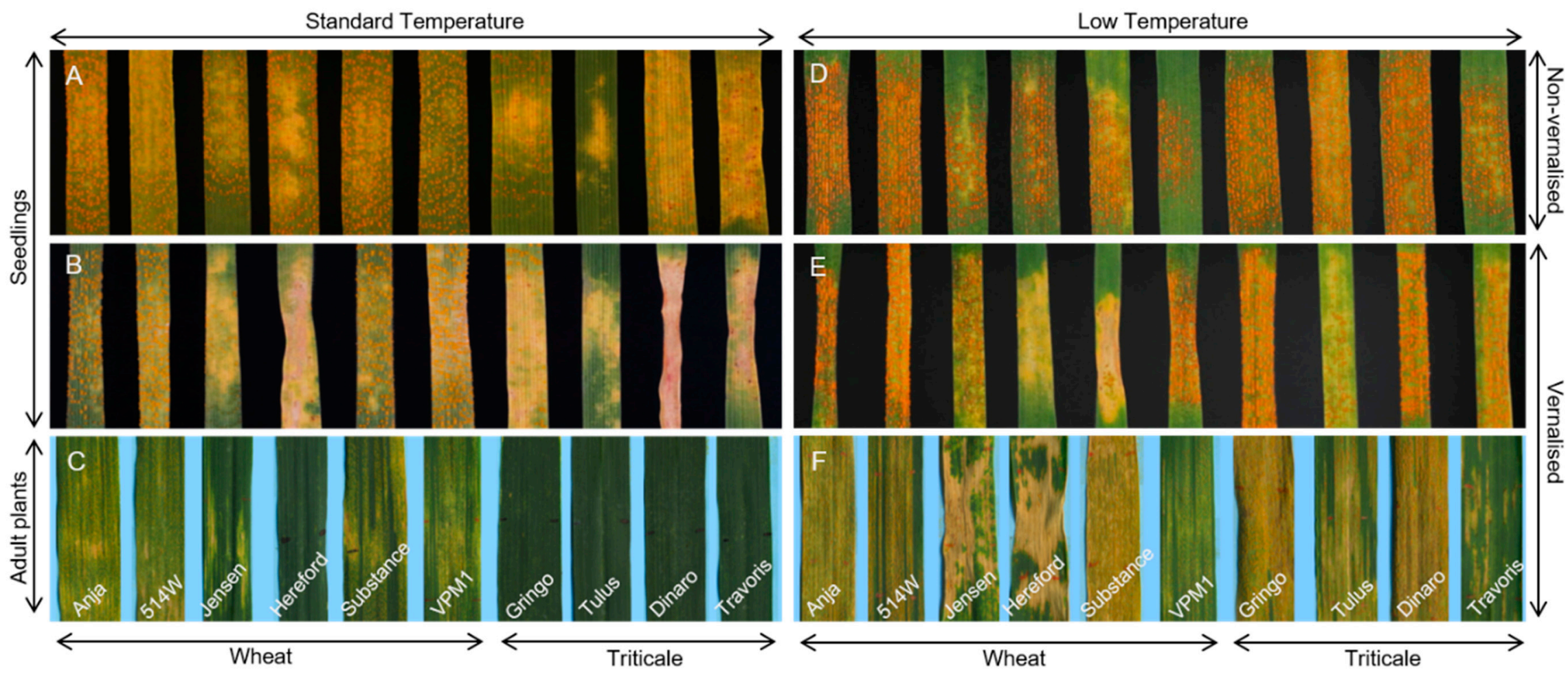

Figure 2. Isolate DK28/12 ('Kranich' race): Effect of vernalisation and temperature regime on yellow rust susceptibility on winter wheat and winter triticale seedlings (second leaf) and adult plants (flag leaf). The leaves are representative of infection types observed across replicates of each variety. Plants in (A-C) were kept at $18^{\circ} \mathrm{C}$ day $/ 12{ }^{\circ} \mathrm{C}$ night (standard temperature). Seedlings were scored 15 days after inoculation (dai) and adult plants 24 dai. Plants in (D-F) were kept at $12{ }^{\circ} \mathrm{C}$ day/ $6{ }^{\circ} \mathrm{C}$ night (low temperature). Seedlings were scored 20 dai and adult plants 28 dai. (A,D): Non-vernalised seedlings. (B,E): Vernalised seedlings. (C,F): Vernalised adult plants. Anja and 514W were included as susceptible controls. 
Overall, the results demonstrate significant shifts in yellow rust susceptibility of particular varieties of winter wheat and winter triticale for particular combinations of host vernalisation, temperature regime, plant growth stage and pathogen race. In the following, the effects of these factors are presented with a focus on combinations of host varieties and treatments, where the effects were most significant.

\subsection{Effect of Vernalisation and Temperature on Seedling Susceptibility}

The influence of vernalisation on seedling susceptibility was more apparent for the 'Warrior' race compared to the 'Kranich' race at the low temperature regime, where significant shifts towards lower infection types (IT) were observed in all varieties, except the two susceptible controls (Anja and 514W) (Figure 3A). At the standard temperature regime, the effect was less evident, but still significant for Jensen and Hereford (wheat) and Gringo, Dinaro and Travoris (triticale) (Figure 3A). For the 'Kranich' race, the effect of vernalisation was significant for Jensen and Hereford (both temperatures) and Substance (low temperature) (Figure 4A). Triticale varieties responded differently to the Kranich race, but all showed lower susceptibility at standard temperature than at low temperature (Figure 4A). Thus, a strong interaction between vernalisation and temperature was observed for Dinaro, whereas the shift towards increased susceptibility for Tulus and Travoris was mainly an effect of temperature. A minor interaction between vernalisation and temperature was observed for Gringo (Figure 4A). For non-vernalised seedlings, low temperature resulted in increased susceptibility on seven varieties (Jensen, Hereford, VPM1, Gringo, Tulus, Dinaro and Travoris) and five varieties (Jensen, Gringo, Tulus, Dinaro and Travoris) inoculated with the 'Warrior' and 'Kranich' races, respectively (Figure 4A). Important shifts in IT due the effect of pathogen race were observed for several wheat and triticale varieties (Figure 3 versus Figure 4), e.g., vernalised seedlings of Tulus and Dinaro at standard temperature and vernalised seedlings of Jensen, VPM1, Tulus, Dinaro and Travoris at low temperature. Less obvious differences were observed on non-vernalised seedlings except for, e.g., Hereford, Tulus and Travoris at standard temperature.

\subsection{Effect of Plant Growth Stage and Temperature on Host Susceptibility}

The effect of plant growth stage was analysed by comparing disease reactions on vernalised seedlings versus vernalised adult plants. For the 'Warrior' race, a reduction in IT from seedling to adult plant growth stage was observed for Jensen, Hereford and VPM1 (wheat) and Tulus and Travoris (triticale) at standard temperature (Figure 3B). At low temperature, this effect was not observed, partly due to low ITs at the seedling stage for most varieties and an increase in IT on adult plants (Figure 3B). For the Kranich race, a minor reduction in IT was detected at standard temperature for Hereford and three triticale varieties (Tulus, Dinaro and Travoris) (Figure 4B). To the contrary, a major shift in IT was observed for Gringo. The effect of plant growth stage at low temperature resulted in significant shifts in IT for Jensen, VPM1 and Travoris (Figure 4B). A minor reduction in IT was detected for Gringo. Generally, adult plants at the low temperature regime resulted in increased susceptibility compared to the standard temperature, i.e., Hereford, VPM1, Gringo, Tulus and Dinaro exposed to the 'Warrior' race, and Hereford, Gringo, Tulus, Dinaro and Travoris exposed to the 'Kranich' race. The effect of pathogen race resulted in changes in susceptibility on adult plants of VPM1, Gringo and Dinaro at standard temperature (Figure 3 versus Figure 4). No significant differences were detected for IT among flag (F) and F-1 leaves of adult plants in each combination of variety, temperature regime and pathogen race ( $p$-value $>0.10$ ) (Supplementary Table S4). 



Wheat
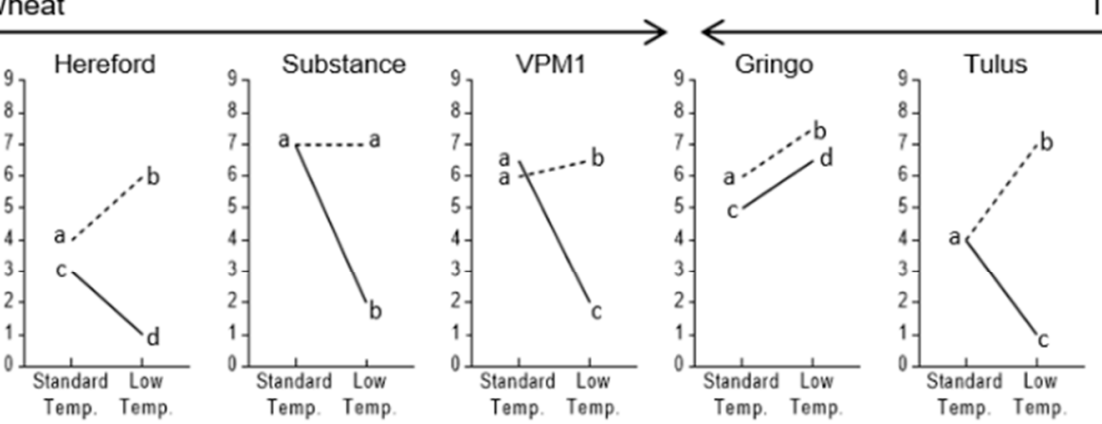

Triticale

..... Non-vernalised seedlings _ - Vernalised seedlings

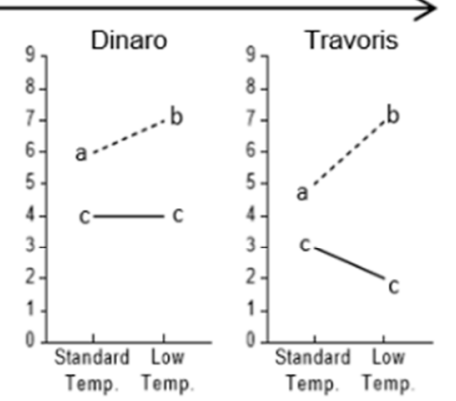

Nentised seedings
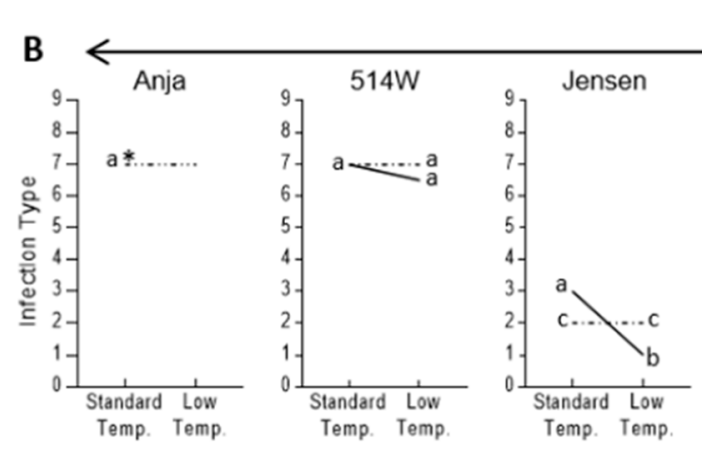

Wheat
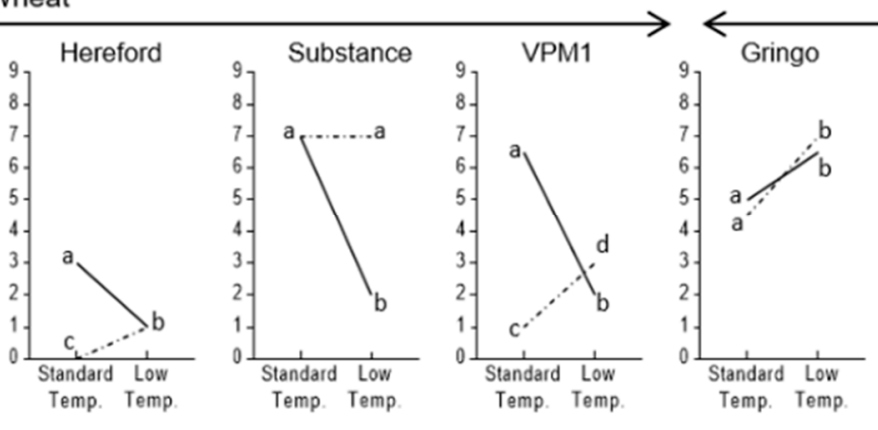

Triticale

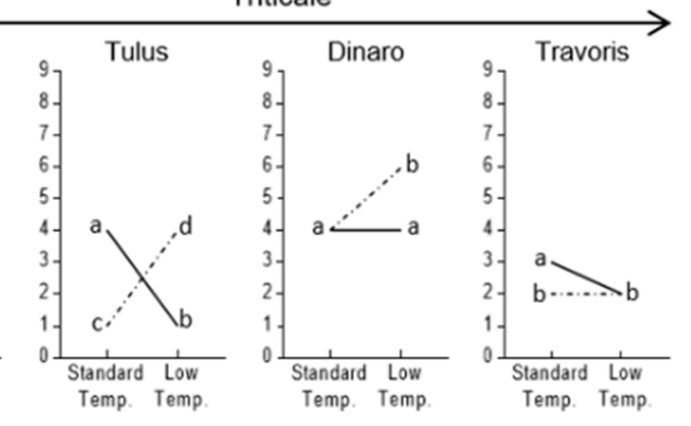

Vernalised seedlings $\quad$........... Vernalised adult-plants

Figure 3. Isolate DK09/11 ('Warrior' race): Infection types on a 0-9 scale [38] represented by the arithmetic median across replicates on varieties of winter wheat and winter triticale at two temperature regimes, i.e., standard $\left(18{ }^{\circ} \mathrm{C}\right.$ day $/ 12{ }^{\circ} \mathrm{C}$ night $)$ and low $\left(12{ }^{\circ} \mathrm{C}\right.$ day/ $6{ }^{\circ} \mathrm{C}$ night). (A): Non-vernalised and vernalised seedlings, (B): Vernalised seedlings and adult plants. Anja and 514W were included as susceptible controls. *: Vernalised Anja at seedling stage was only assessed at standard temperature. Same letters indicate non-significant differences among treatments at $p$-value $\leq 0.05$ (a single letter was included when two lines were confluent at the same temperature regime). 


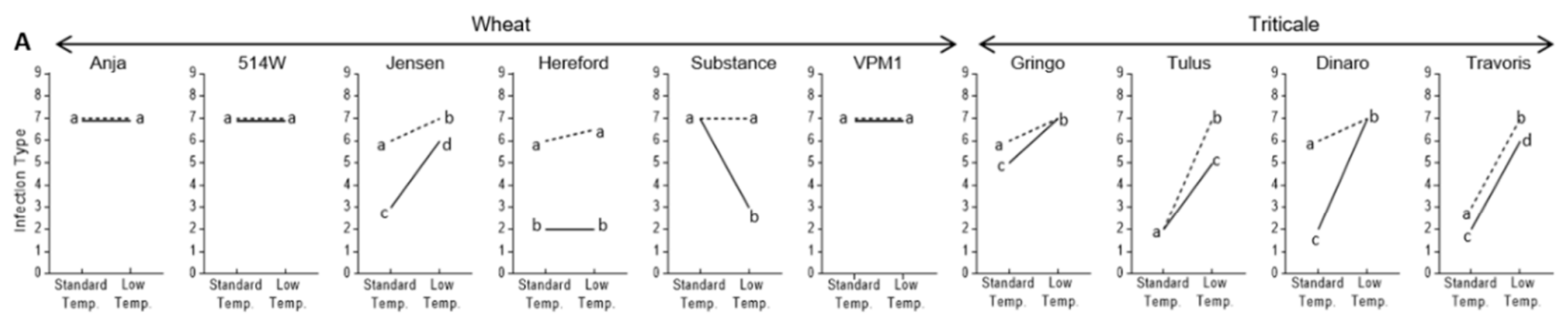

..... Non-vernalised seedlings $\quad$ - Vemalised seedlings

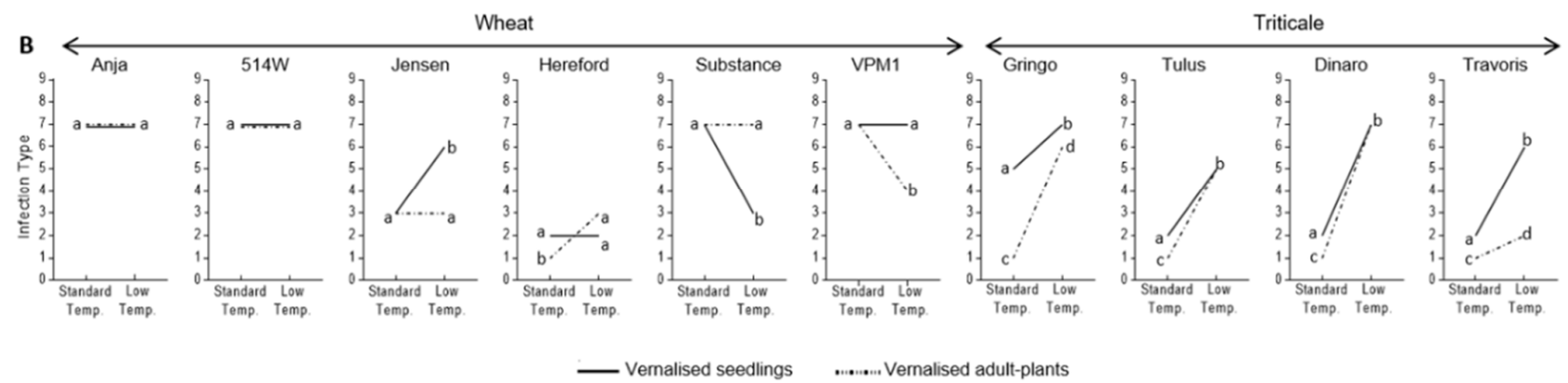

Figure 4. Isolate DK28/12 ('Kranich' race): Infection types on a 0-9 scale [38] represented by the arithmetic median across replicates on varieties of winter wheat and winter triticale at two temperature regimes, i.e., standard $\left(18{ }^{\circ} \mathrm{C}\right.$ day $/ 12{ }^{\circ} \mathrm{C}$ night), and low $\left(12{ }^{\circ} \mathrm{C}\right.$ day $/ 6{ }^{\circ} \mathrm{C}$ night $)$. (A): Non-vernalised and vernalised seedlings, (B): Vernalised seedlings and adult plants. Anja and 514W were included as susceptible controls. Same letters indicate non-significant differences among treatments at $p$-value $\leq 0.05$ (a single letter was included when two lines were confluent at the same temperature regime). 


\section{Discussion}

The experimental system in this study comprised two temperature regimes, vernalised and non-vernalised seedlings of winter wheat and winter triticale varieties, vernalised adult plants and two Puccinia striiformis races, which enabled us to investigate the main effects as well as complex interactions among these factors on disease susceptibility. This allowed us to demonstrate that yellow rust susceptibility of winter cereals can be highly influenced by vernalisation, temperature, plant growth stage and pathogen race, often resulting in unpredictable shifts in host susceptibility for particular combinations of these factors. The experimental setup proved to be effective regarding high inoculation and infection success rates and for investigating both environmental and genetic effects influencing host-pathogen interactions. The manual removal of diseased leaves from vernalised seedlings enabled us to reuse the experimental plants throughout the experiment, thereby directly connecting seedling and adult plant results. This leaf detachment in seedlings did not influence resistance responses at the adult plant stage, as confirmed by compatible interactions observed on the controls Anja and 514W, and several other varieties for particular combinations of pathogen race and temperature. Thus, we observed no indication of systemic acquired resistance responses in this experimental setup, which is otherwise a frequently described phenomenon in wheat [46].

Vernalisation of overwintering cereals and grasses can enhance disease resistance to several fungal pathogens, e.g., snow moulds (Microdochium nivale and Typhula ishikariensis) $[6,47,48]$, powdery mildew (Blumeris graminis f.sp. hordei) [10] and the rust fungus Puccinia poae-nemoralis [49]. This type of disease resistance, developed during prolonged exposure to low temperatures, has been ascribed to the production of pathogenesis-related (PR) proteins, e.g., $\beta$-1,3-glucanases, chitinases and thaumatin-like proteins, during vernalisation, which are involved in the degradation of fungal cell walls $[5,6,50,51]$. Recent studies have suggested that epigenetic mechanisms such as DNA demethylation take part in plant immune responses against pathogenic fungi and bacteria by enhancing and maintaining the expression of defence related-genes [52-54]. In fact, the level of demethylation can be altered in response to vernalisation in addition to exposure to low-temperature stress during plant growth, resulting in an increase in gene expression [55-58]. Our results showed that vernalised seedlings inoculated with the 'Warrior' race and Hereford and Substance inoculated with the 'Kranich' race and maintained at a low temperature, resulted in a significant reduced susceptibility compared to non-vernalised plants. Restricted pustule development was observed on some of these vernalised seedlings, especially the susceptible control Anja, which might be ascribed to slow development of compatible interactions at low temperature. However, re-scoring at a later stage showed no indications of new uredinial pustules or expansion of the already erupted ones, indicating that resistance mechanisms were still effective. The effect of vernalisation on host susceptibility described above might be attributed to DNA demethylation and subsequent activation of genes involved in host resistance during vernalisation and maintained at low temperature. Although, much progress has been made to understand how demethylated genes involved in host resistance can be inherited over several plant generations, the exact mechanisms are not yet fully understood $[56,59,60]$. Here, reduced yellow rust susceptibility after vernalisation was also observed for several varieties at standard temperature, indicating variable effects due to temperature, pathogen race and the genetic background of the varieties.

The influence of temperature on susceptibility to $P$. striiformis has long been recognised, where the expression and effectiveness of resistance genes can vary depending on the temperature before and after infection $[12,61,62]$. Our results suggest that temperature strongly influenced the susceptibility of winter wheat and triticale to $P$. striiformis. Both seedlings and adult plants of several varieties revealed a lower IT at standard temperature compared to the low temperature regime. These results were similar to previous studies of resistance to yellow rust, where wheat varieties showed a reduced susceptibility at higher temperature regimes $[11,18]$. The increased susceptibility at low temperature was particularly evident for triticale varieties inoculated with the 'Kranich' race. Triticale is a hybrid of wheat (Triticum spp.) and rye (Secale cereale L.), both may provide sources of disease resistance, as previously reported for, e.g., P. striiformis, P. graminis, and P. triticina [63-66], but only expressed 
at specific temperature regimes. Whether the resistance response observed in triticale was due to the effect of resistance genes from wheat and/or rye remains to be further elucidated. In summary, the complex interactions among all the factors may cause unexpected disease reactions for particular varieties on specific sites and in specific years.

The effectiveness of genes for resistance to $P$. striiformis can be highly influenced by the plant growth stage of the host variety. Furthermore, the detection of specific types of resistance may be achieved by exposing a variety to specific temperature regimes before and after pathogen infection $[12,15,18,25]$. Our experimental setup allowed for disentangling the effects of vernalisation from plant growth stage, which are often confounded in experiments involving winter cereals. The fact that vernalisation reduced disease susceptibility on specific seedling varieties at standard temperature might be of particular interest for studies aiming to detect genes conferring adult plant resistance (APR) in winter cereals. When phenotyping for disease resistance, the use of vernalised seedlings may provide a better indication of the type of resistance involved in adult plants, especially at standard temperature, which is in the range of temperatures commonly used in host susceptibility studies of $P$. striiformis $[17,67]$. In the present study, APR was detected in some varieties and often showed race specificity. For instance, APR was observed for VPM1 inoculated with the 'Warrior' race and maintained at standard temperature. For the 'Kranich' race, the compatible and incompatible interactions observed on seedlings and adult plants respectively, of Jensen and Travoris, at low temperature, indicated the presence of APR. In some cases, it was not possible to clearly detect if APR was involved, probably because it was masked by the effect of seedling resistance genes, e.g., Jensen and Travoris at standard temperature ('Warrior' race) and Tulus, Dinaro and Travoris at standard temperature ('Kranich' race) [68]. Although the low temperature regime use in this study may represent atypical field conditions for adult plants during spring-summer, this allowed us to detect specific interactions. The above observations emphasized the importance of vernalisation, temperature and pathogen race when conducting host susceptibility studies to cereal rusts.

\section{Conclusions}

In the case of plant breeding, the results stress the importance of phenotyping for disease resistance under multiple and different environmental conditions. The novel findings of increased yellow rust susceptibility for specific combinations of vernalisation, temperature, variety and pathogen race should be taken into account in the decision making for the deployment of winter cereals and in rust early-warning systems targeting wheat and triticale breeding programmes and growers. Further studies including additional temperature regimes, pathogen races of different origin and varieties carrying well-characterised resistance genes and with different vernalisation requirements would allow a broader understanding of the effect of environmental conditions on host susceptibility to P. striiformis. Moreover, gene expression studies aiming to identify temperature-sensitive genes would provide an improved comprehension on how vernalisation and temperature may influence host susceptibility to P. striiformis. These future investigations may help to breed varieties carrying more temperature-stable resistance genes and avoid exploitation of the most sensitive ones, which may adversely affect the performance of host varieties under natural conditions [12]. A major take home message of this study is that disease susceptibility of crop plants is highly dependent on temperature, host physiology, pathogen race and complex interactions among these factors. In addition, this study illustrates how difficult it may be to predict the impact of more extreme and unpredictable weather patterns on plant disease epidemiology.

Supplementary Materials: The following are available online at http://www.mdpi.com/2073-4395/10/1/13/s1: Figure S1: Box plots displaying the variability observed on infection types on a 0-9 scale across replicates [38]. A: DK09/11 ('Warrior' race); non-vernalised seedlings and vernalised seedlings and adult-plants. B: DK28/12 ('Kranich race); non-vernalised seedlings and vernalised seedlings and adult-plants. Winter wheat and winter triticale varieties were maintained at two temperature regimes, i.e., standard $\left(18{ }^{\circ} \mathrm{C}\right.$ day $/ 12{ }^{\circ} \mathrm{C}$ night $)$ and low $\left(12{ }^{\circ} \mathrm{C}\right.$ day $/ 6^{\circ} \mathrm{C}$ night). Horizontal and intersecting lines within an individual boxplot and + symbols indicate the calculated median among all replicates. Anja and 514W were included as susceptible controls. *: Vernalised wheat 
variety Anja at seedling stage not assessed at low temperature. Table S1: Number of scored and escaped (failed inoculations) observations of vernalised and non-vernalised seedlings of winter wheat and winter triticale varieties after inoculation with two Puccinia striiformis races and maintained at two temperature regimes, i.e., $18{ }^{\circ} \mathrm{C}$ day $/ 12{ }^{\circ} \mathrm{C}$ night (standard temperature) and $12{ }^{\circ} \mathrm{C}$ day $/ 6^{\circ} \mathrm{C}$ night (low temperature). Table S2: Number of flag $(\mathrm{F})$ and F-1 leaves scored, escaped (failed inoculations) and senescent of adult winter wheat and triticale varieties after inoculation with two Puccinia striiformis races and maintained at two temperature regimes, i.e., $18^{\circ} \mathrm{C}$ day $/ 12{ }^{\circ} \mathrm{C}$ night (standard temperature) and $12{ }^{\circ} \mathrm{C}$ day $/ 6^{\circ} \mathrm{C}$ night (low temperature). Table S3: Effect of Puccinia striiformis race on the proportion of successful inoculations on seedlings and adult plants across treatments described in Tables S1 and S2. Table S4: Effect of leaf number, i.e., flag (F) and F-1 leaves, of adult plants on host susceptibility to Puccinia striiformis for each combination of pathogen race, temperature regime, and variety indicated by $p$-values. Significant differences detected at $p \leq 0.05$.

Author Contributions: J.R.-A. carried out the experimental work. J.R.-A., M.S.H., A.F.J., C.K.S., and R.L. analysed and interpreted the data. M.S.H., C.K.S., A.F.J., and J.R.-A. conceived and designed the study. J.R.-A. and M.S.H. wrote the manuscript with contributions from co-authors. All authors revised and approved the final manuscript. All authors have read and agreed to the published version of the manuscript.

Funding: The research project was funded by Aarhus University, the Ministry of Environment and Food of Denmark (grant number 34009-12-0568) and Innovation Fund Denmark, Ministry of Higher Education and Science (grant number 4105-00022B).

Acknowledgments: We thank S. Meier and E. Jørgensen for technical assistance during the experimental work, including pathogen isolate multiplication. J. Reitan is thanked for his input in relation to the effect of vernalisation on plant defence.

Conflicts of Interest: The authors declare no conflict of interest.

\section{References}

1. Chouard, P. Vernalization and its relations to dormancy. Annu. Rev. Plant Physiol. 1960, 11, 191-238. [CrossRef]

2. Amasino, R. Vernalization, Competence, and the Epigenetic Memory of Winter. Plant Cell 2004, 16, $2553-2559$. [CrossRef] [PubMed]

3. Thomashow, M.F. Plant cold cclimation: Freezing Tolerance Genes and Regulatory Mechanisms. Annu. Rev. Plant Physiol. 1999, 50, 571-599. [CrossRef] [PubMed]

4. Hon, W.; Griffith, M.; Mlynarz, A.; Kwok, Y.C.; Yang, D.S.C. Antifreeze Proteins in Winter Rye Are Similar to Pathogenesis-Related Proteins. Plant Physiol. 1995, 109, 879-889. [CrossRef] [PubMed]

5. Griffith, M.; Yaish, M.W. Antifreeze proteins in overwintering plants: A tale of two activities. Trends Plant Sci. 2004, 9, 399-405. [CrossRef] [PubMed]

6. Kuwabara, C.; Imai, R. Molecular Basis of Disease Resistance Acquired through Cold Acclimation in Overwintering Plants. J. Plant Biol. 2009, 52, 19-26. [CrossRef]

7. Ergon, A.; Klemsdal, S.S.; Tronsmo, A.M. Interactions between cold hardening and Microdochium nivale infection on expression of pathogenesis-related genes in winter wheat. Physiol. Mol. Plant Pathol. 1998, 53, 301-310. [CrossRef]

8. Gaudet, D.A.; Laroche, A.; Frick, M.; Huel, R.; Puchalski, B. Plant development affects the cold-induced expression of plant defence-related transcripts in winter wheat. Physiol. Mol. Plant Pathol. 2003, 62, 175-184. [CrossRef]

9. Nakajima, T.; Abe, J. Environmental factors affecting expression of resistance to pink snow mold caused by Microdochium nivale in winter wheat. Can. J. Bot. 1996, 74, 1783-1788. [CrossRef]

10. White, N.; Jenkyn, J.F. Effects of sowing date and vernalisation on the growth of winter barley and its resistance to powdery mildew (Erysiphe graminis f.sp. hordei). Ann. Appl. Biol. 1995, 218, 269-283. [CrossRef]

11. Qayoum, A.; Line, R.F. High-Temperature, Adult Plant Resistance to Stripe Rust of Wheat. Phytopathology 1985, 75, 1121-1125. [CrossRef]

12. Bryant, R.R.M.; McGrann, G.R.D.; Mitchell, A.R.; Schoonbeek, H.; Boyd, L.A.; Uauy, C.; Dorling, S.; Ridout, C.J. A change in temperature modulates defence to yellow (stripe) rust in wheat line UC1041 independently of resistance gene Yr36. BMC Plant Biol. 2014, 14, 10. [CrossRef] [PubMed]

13. Fetch, T.G., Jr. Effect of temperature on the expression of seedling resistance to Puccinia graminis f. sp. avenae in oat. Can. J. Plant Pathol. 2006, 28, 558-565. [CrossRef]

14. Brown, G.N. The inheritance and expression of leaf chlorosis associated with gene Sr2 for adult plant resistance to wheat stem rust. Euphytica 1997, 95, 67-71. [CrossRef] 
15. Broers, L.H.M.; Wallenburg, S.C. Influence of post-infection temperature on three components of partial resistance in wheat to wheat leaf rust. Euphytica 1989, 44, 215-224. [CrossRef]

16. Dyck, P.L.; Johnson, R. Temperature sensitive of genes for resistance in wheat to Puccinia recondita. Can. J. Plant Pathol. 1983, 5, 229-234. [CrossRef]

17. Stubbs, R.W. Stripe Rust, The Cereal Rusts Vol. II: Diseases, Distribution, Epidemiology, and Control; Roelfs, A.P., Bushnell, W.R., Eds.; Academic Press: Orlando, FL, USA, 1985; pp. 77-115.

18. Park, R.; Ash, G.; Rees, R. Effects of temperature on the response of some Australian wheat varieties to Puccinia striiformis f. sp. Tritici. Mycol. Res. 1992, 96, 166-170. [CrossRef]

19. Bariana, H.S.; McIntosh, R.A. Characterisation and origin of rust and powdery mildew resistance genes in VPM1 wheat. Euphytica 1994, 76, 53-61. [CrossRef]

20. Pretorius, Z.A.; Kloppers, F.J.; Drijepondt, S.C. Effects of inoculum density and temperature on 3 components of leaf rust resistance controlled by Lr34 in wheat. Euphytica 1994, 74, 91-96. [CrossRef]

21. Flor, H.H. Host-parasite interaction in flax rust-its genetics and other implications. Phytopathology 1955, 45, 680-685.

22. Jones, J.D.; Dangl, J.L. The plant immune system. Nature 2006, 444, 323-329. [CrossRef] [PubMed]

23. Boyd, L.A. Can Robigus defeat an old enemy?-Yellow rust of wheat. J. Agric. Sci. 2005, 143, 233. [CrossRef]

24. Johnson, R. A Critical Analysis of Durable Resistance. Annu. Rev. Phytopathol. 1984, 22, 309-330. [CrossRef]

25. Pretorius, Z.A.; Pienaar, L.; Prins, R. Greenhouse and field assessment of adult plant resistance in wheat to Puccinia striiformis f. sp. Tritici. Australas. Plant Pathol. 2007, 36, 552-559. [CrossRef]

26. Johnson, R. Past, present and future opportunities in breeding for disease resistance, with examples from wheat. Euphytica 1992, 63, 3-22. [CrossRef]

27. Singh, R.P.; Herrera-Foessel, S.; Huerta-Espino, J.; Singh, S.; Bhavani, S.; Lan, C.; Basnet, B.R. Progress Towards Genetics and Breeding for Minor Genes Based Resistance to Ug99 and Other Rusts in CIMMYT High-Yielding Spring Wheat. J. Integr. Agric. 2014, 13, 255-261. [CrossRef]

28. Ellis, J.G.; Lagudah, E.S.; Spielmeyer, W.; Dodds, P.N. The past, present and future of breeding rust resistant wheat. Front. Plant Sci. 2014, 5, 641. [CrossRef]

29. Chen, X. High-Temperature Adult-Plant Resistance, Key for Sustainable Control of Stripe Rust. Am. J. Plant Sci. 2013, 4, 608-627. [CrossRef]

30. Hovmøller, M.S.; Walter, S.; Bayles, R.A.; Hubbard, A.; Flath, K.; Sommerfeldt, N.; Leconte, M.; Czembor, P.; Rodriguez-Algaba, J.; Thach, T.; et al. Replacement of the European wheat yellow rust population by new races from the centre of diversity in the near-Himalayan region. Plant Pathol. 2016, 65, 402-411. [CrossRef]

31. Hovmøller, M.S.; Justesen, A.F. Appearance of atypical Puccinia striiformis f. sp. tritici phenotypes in northwestern Europe. Aust. J. Agric. Res. 2007, 58, 518. [CrossRef]

32. Thach, T.; Ali, S.; Justesen, A.F.; Rodriguez-Algaba, J.; Hovmøller, M.S. Recovery and virulence phenotyping of the historic 'Stubbs collection' of the yellow rust fungus Puccinia striiformis from wheat. Ann. Appl. Biol. 2015, 167, 314-326. [CrossRef]

33. Bariana, H.S.; McIntosh, R.A. Cytogenetic studies in wheat. XV. Location of rust resistance genes in VPM1 and their genetic linkage with other disease resistance genes in Chromosome 2A. Genome 1993, 36, 476-482. [CrossRef] [PubMed]

34. Hovmøller, M.S. Sources of seedling and adult plant resistance to P. striiformis f. sp. tritici in European wheats. Plant Breed. 2007, 126, 225-233.

35. Milus, E.A.; Moon, D.E.; Lee, K.D.; Mason, R.E. Race-Specific Adult-Plant Resistance in Winter Wheat to Stripe Rust and Characterization of Pathogen Virulence Patterns. Phytopathology 2015, 105, 1114-1122. [CrossRef]

36. Sørensen, C.K.; Thach, T.; Hovmøller, M.S. Evaluation of Spray and Point Inoculation Methods for the Phenotyping of Puccinia striiformis on Wheat. Plant Dis. 2016, 100, 1064-1070. [CrossRef]

37. Milus, E.A.; Kristensen, K.; Hovmoller, M.S. Evidence for increased aggressiveness in a recent widespread strain of Puccinia striiformis f. sp. tritici causing stripe rust of wheat. Phytopathology 2009, 99, 89-94. [CrossRef]

38. McNeal, F.H.; Konzak, C.F.; Smith, E.P.; Tate, W.S.; Russel, T.S. A uniform system for recording and processing cereal research data. USDA Agric. Res. Serv. 1971, 42, 34-121.

39. Zadoks, J.C.; Chang, T.T.; Konzak, C.F. A decimal code for the growth stages of cereals. Weed Res. 1974, 14, 415-421. [CrossRef]

40. McCullagh, P.; Nelder, J.A. Generalized Linear Models; Chapman and Hall: London, UK, 1989. 
41. Jørgensen, B.; Labouriau, R.; Lundbye-Christensen, S. Linear growth curve analysis based on exponential dispersion models. J. R. Stat. Soc. 1996, 58, 573-592. [CrossRef]

42. Lehmann, E. Nonparametrics: Statistical Methods Based on Ranks; Springer: New York, NY, USA, 2006.

43. Benjamini, Y.; Yekutieli, D. The control of the false discovery rate in multiple testing under dependency. Ann. Stat. 2001, 29, 1165-1188.

44. Benjamini, Y.; Hochberg, Y. Controlling the false discovery rate: A practical and powerful approach to multiple testing. J. R. Stat. Soc. 1995, 57, 289-300. [CrossRef]

45. R Core Team. A Language and Environment for Statistical Computing; R Foundation for Statistical Computing: Vienna, Austria, 2019.

46. Walters, D.; Walsh, D.; Newton, A.; Lyon, G. Induced Resistance for Plant Disease Control: Maximizing the Efficacy of Resistance Elicitors. Phytopathology 2005, 95, 1368-1373. [CrossRef] [PubMed]

47. Hofgaard, I.S.; Wanner, L.A.; Tronsmo, A.M. The effect of age and cold hardening on resistance to pink snow mould (Microdochium nivale) in perennial ryegrass (Lolium perenne L.). Acta Agric. Scand. Sect. B Plant Soil Sci. 2006, 56, 315-323.

48. Tronsmo, A.M. Host water potentials may restrict development of snow mould fungi in low temperature-hardened grasses. Physiol. Plant. 1986, 68, 175-179. [CrossRef]

49. Tronsmo, A.M. Resistance to the rust fungus Puccinia poae-nemoralis in Poa pratensis induced by low-temperature hardening. Can. J. Bot. 1984, 62, 2891-2892. [CrossRef]

50. Gaudet, D.A.; Laroche, A.; Frick, M.; Davoren, J.; Puchalski, B.; Ergon, Å. Expression of plant defence-related (PR-protein) transcripts during hardening and dehardening of winter wheat. Physiol. Mol. Plant Pathol. 2000, 57, 15-24. [CrossRef]

51. Liu, J.J.; Sturrock, R.; Ekramoddoullah, A.K. The superfamily of thaumatin-like proteins: Its origin, evolution, and expression towards biological function. Plant Cell Rep. 2010, 29, 419-436. [CrossRef]

52. Lopez-Sanchez, A.; Stassen, J.H.; Furci, L.; Smith, L.M.; Ton, J. The role of DNA (de)methylation in immune responsiveness of Arabidopsis. Plant J. 2016, 88, 361-374. [CrossRef]

53. Tuan-Ngoc, L.; Schumann, N.U.; Smith, N.A.; Tiwari, S.; Au, P.C.K.; Zhu, Q.; Taylor, J.M.; Kazan, K.; Llewellyn, D.J.; Zhang, R.; et al. DNA demethylases target promoter transposable elements to positively regulate stress responsive genes in Arabidopsis. Genome Biol. 2014, 15, 458.

54. Yu, A.; Lepere, G.; Jay, F.; Wang, J.; Bapaume, L.; Wang, Y.; Abraham, A.L.; Penterman, J.; Fischer, R.L.; Voinnet, O.; et al. Dynamics and biological relevance of DNA demethylation in Arabidopsis antibacterial defense. Proc. Natl. Acad. Sci. USA 2013, 110, 2389-2394. [CrossRef]

55. Steward, N.; Ito, M.; Yamaguchi, Y.; Koizumi, N.; Sano, H. Periodic DNA methylation in maize nucleosomes and demethylation by environmental stress. J. Biol. Chem. 2002, 277, 37741-37746. [CrossRef] [PubMed]

56. Peng, H.; Zhang, J. Plant genomic DNA methylation in response to stresses: Potential applications and challenges in plant breeding. Prog. Nat. Sci. 2009, 19, 1037-1045. [CrossRef]

57. Sherman, J.D.; Talbert, L.E. Vernalization-induced changes of the DNA methylation pattern in winter wheat. Genome 2002, 45, 253-260. [CrossRef]

58. Finnegan, E.J.; Genger, R.K.; Peacock, W.J.; Dennis, E.S. DNA METHYLATION IN PLANTS. Annu. Rev. Plant Physiol. Plant Mol. Biol. 1998, 49, 223-247. [CrossRef] [PubMed]

59. Akimoto, K.; Katakami, H.; Kim, H.J.; Ogawa, E.; Sano, C.M.; Wada, Y.; Sano, H. Epigenetic inheritance in rice plants. Ann. Bot. 2007, 100, 205-217. [CrossRef] [PubMed]

60. Gardiner, L.J.; Quinton-Tulloch, M.; Olohan, L.; Price, J.; Hall, N.; Hall, A. A genome-wide survey of DNA methylation in hexaploid wheat. Genome Biol. 2015, 16, 273. [CrossRef]

61. Brown, J.F.; Sharp, E.L. Interactions of minor host genes for resistance to Puccinia striiformis with changing temperatures. Phytopathology 1969, 59, 999-1001.

62. Zadoks, J.C. Yellow rust on wheat, studies in epidemiology and physiologic specialization. Tijdschrift Over Plantenziekten 1961, 67, 69-256. [CrossRef]

63. Mergoum, M.; Pfeiffer, W.H.; Peña, R.J.; Ammar, K.; Rajaram, S. Triticale crop improvement: The CIMMYT programme. In Triticale Improvement and Production; Food and Agriculture Organization of the United Nations: Rome, Italy, 2004.

64. Crespo-Herrera, L.A.; Garkava-Gustavsson, L.; Ahman, I. A systematic review of rye (Secale cereale L.) as a source of resistance to pathogens and pests in wheat (Triticum aestivum L.). Hereditas 2017, 154, 14. [CrossRef] 
65. Friebe, B.; Jiang, J.; Raupp, W.J.; Mclntosh, R.A.; Gill, B.S. Characterization of wheat-alien translocations conferring resistance to diseases and pests: Current status. Euphytica 1996, 91, 59-87. [CrossRef]

66. Tyrka, M.; Chekowski, J. Enhancing the resistance of triticale by using genes from wheat and rye. J. Appl. Genet. 2004, 45, 283-295. [PubMed]

67. Milus, E.A.; Lee, K.D.; Brown-Guedira, G. Characterization of Stripe Rust Resistance in Wheat Lines with Resistance Gene Yr17 and Implications for Evaluating Resistance and Virulence. Phytopathology 2015, 105, 1123-1130. [CrossRef] [PubMed]

68. Riaz, A.; Periyannan, S.; Aitken, E.; Hickey, L. A rapid phenotyping method for adult plant resistance to leaf rust in wheat. Plant Methods 2016, 12, 17. [CrossRef] [PubMed]

(C) 2019 by the authors. Licensee MDPI, Basel, Switzerland. This article is an open access article distributed under the terms and conditions of the Creative Commons Attribution (CC BY) license (http://creativecommons.org/licenses/by/4.0/). 